\title{
Exploring the English Needs of Mechanical Engineering Students in ESP Class: Indonesian University Context
}

\author{
Angga Nafis Akmal \\ Universitas Muhammadiyah Malang \\ Nur Hidayati \\ Universitas Muhammadiyah Malang \\ Rafika Rabba Farah \\ Universitas Muhammadiyah Malang
}

Corresponding Author: rafikafarah@gmail.com

\begin{abstract}
English for Specific Purposes in tertiary level puts its importance to Need Analysis (NA) process for syllabus design. This present research is concerned with designing ESP syllabus for Mechanical Engineering students in tertiary level through need analysis. The research aims to identify the immediate needs of the Mechanical Engineering students and design appropriated syllabus based on students' needs using Target Situation Analysis (TSA) and Present Situation Analysis (PSA). In order to achieve the research's objectives, a questionnaire was administered to a total 50 respondents. The finding of the research shows that among 4 basic English skills, listening skill emerged as the most important skill that students' really need, followed by speaking, reading, and writing. Thus, this research suggests that ESP teachers should design more varied activities on listening course that students will have the competence to apply the skills later in future life context.
\end{abstract}

Keyword: Syllabus, English for Specific Purposes, Mechanical Engineering, Need Analysis

\section{INTRODUCTION}

As English continuous to dominate in business, technology, media, education, medicine, and research, English for Specific Purposes (ESP) has become a key part of English as foreign language teaching around the world. According to Saragih (2014), ESP itself is a program that prepares the learners to use English in academic (students of different fields), professional (people of different professions such as doctors, engineers, and nurses), and workplace (technicians for example) settings. Therefore, some universities around the worlds add ESP as a compulsory program to make sure their students ready to face the globalization era which applies English as international language.

In Indonesia, one of the universities that adds ESP as the compulsory program is University of Muhammadiyah Malang (UMM). According to Poedjiastutie (2017), in UMM, ESP is the Language Center program is designed for all freshmen enrolled at the university. During the first year (two semesters) of their studies, students in both the English and non- 
Angga Nafis Akmal, Nur Hidayati, Rafika Rabba Farah
Exploring the English Needs of Mechanical Engineering Students in ESP Class: Indonesian University Context

English Departments take different ESP courses depending on their majors. However, in some cases, the ESP course cannot fulfill what students really need. It is because some students are given General English (GE). Indeed, according to Williams (2014), the goal of ESP is learners can achieve a competence in a specific domain of English and an essentially practical goal coming within the wider field of applied linguistics. To design an appropriate syllabus for ESP, Kaur \& Khan (2010) suggest to focus on primary issue that is the analysis of learners' specific needs, it needs to be elicited through need analysis (Boroujeni \& Fard, 2013 and Li, 2014).

The major importance of need analysis in ESP program has been conducted in many engineering students around the world on different disciplines. Izidi \& Zetouni (2017) on their study on Mechanical Engineering students at the University of Sciences and Technology, Oran U.S.T.O reveal that the students have positive attitude toward ESP learning. Also, the students have the preference on being taught with a mixture between ESP and General English. Further, a study on Food Engineering students has found that the students are in a lack competence to English skills, whereas they have a great interest to improve their oral competence and want to master specific vocabularies related to their future job (Mihalache, 2015).

Likewise, Hossain (2013) also conducted a need analysis on School of Engineering Students at Presidency University Dhaka. He carries the implementation of need analysis using the framework of Target Situation, Present Situation, and Contextual Situation. Result shows that the respondents are in average level of English proficiency and they are in a greatest need to content-related material. It is suggested that students are equipped with more exposure to writing skill and speaking performance. Another, a need analysis on Petroleum Engineering students at Hadhramout University of science and Technology Yemen has focused on students' lack, want, and necessity on ESP course. The major findings discover that among 4 English basic skills, listening is perceived as the most frequent skill used by the students, following it writing, reading, then speaking.

However, of the four previous research findings, a need analysis to Mechanical Engineering students at Indonesian setting is still fairly limited. Also, this present research is implemented using Target Situation Analysis (TSA) and Present Situation Analysis (PSA) focusing on the importance of skill and subskill. Using the concept, this research aims to reveal students immediate need on learning ESP at Mechanical Engineering students using PSA and TSA approach. Thus, the result of this study will have a significant contribution on ESP teaching material development in general and in particular to highlight the students' English use in the actual context.

\section{METHOD}

\section{Research Design}

Research design can be defined as all of the researchers' plan and strategy to answer research problems of study. Ary, Jacobs, Sorensen, \& Razavieh (2010) states that research design is the researchers' plan of how to proceed to gain an understanding of some groups or some phenomenon's in its natural setting. There are some research designs such as quantitative, qualitative and mix method research design. The researchers decided to use quantitative research design because it was dealing with the number and using statistical analysis. 
Angga Nafis Akmal, Nur Hidayati, Rafika Rabba Farah
Exploring the English Needs of Mechanical Engineering Students in ESP Class: Indonesian University Context

\section{Research Instrument}

The research instrument used by the researchers is questionnaire. The questionnaire was chosen to make the easy both for researcher or participant as stated by Latief (2017), the questionnaire is easy to fill out and takes little time. The questionnaire is adapted from Alsamadani (2017). The questionnaire is composed 44 items covers statement about the importance of each language skill, and sub-skill. The questionnaire is based on the 4-point Likert scale with "very important", "important", "unimportant", and "very unimportant". The questionnaire was distributed to 50 students. To make items easy to be understood, the researchers translated the questionnaire into Bahasa.

\section{Research Setting and Participants}

The research setting was University of Muhammadiyah Malang. The respondents were 50 UMM Mechanical Engineering students. Those students were taken as sample of Mechanical Engineering student population. The participants are taken from 2 classes consist of class C (15) and D (35). All participants were freshmen who enrolled for academic year 2018-2019.

\section{Data Analysis}

To analyze the data, the researchers adapt steps of data analysis from Al- Hamlan, (2015). The steps of data analysis are presented below:

1. The questionnaires were collected and put for analysis.

2. The means and standard deviation for each statement were extracted and analyzed using simple statistical analysis tool, using mean and standard deviation calculator (miniwebtool.com).

3. The data were tabulated in order to make it more understandable.

4. Then, findings were discussed and analyzed.

\section{FINDINGS AND DISCUSSION}

The result of questionnaire will be presented in table 1, 2, 3, 4, and 5. Table 1 shows the importance of each 4 basic English Skill. The table 2, 3, 4 and 5 show the importance of sub-skills of each 4 basic English skills. The detail of result can be seen below:

Table 1. The importance of each 4 basic English skill.

\begin{tabular}{lcccccc}
\hline English Language Skill & VI & I & U & VU & Mean & SD \\
\hline Listening & 30 & 19 & 1 & 0 & 3.58 & 0.53 \\
\hline Speaking & 31 & 16 & 1 & 0 & 3.56 & 0.61 \\
\hline Reading & 22 & 24 & 4 & 0 & 3.36 & 0.63 \\
\hline Writing & 18 & 26 & 6 & 0 & 3.24 & 0.65 \\
\hline
\end{tabular}

Table 2. The importance of each listening sub-skill. 
Angga Nafis Akmal, Nur Hidayati, Rafika Rabba Farah
Exploring the English Needs of Mechanical Engineering Students in ESP Class: Indonesian University Context

\begin{tabular}{|c|c|c|c|c|c|c|}
\hline Sub-skill Listening & VI & $\mathbf{I}$ & $\mathbf{U}$ & $\mathbf{V U}$ & Mean & SD \\
\hline Listening to foreign manager & 15 & 29 & 0 & 2 & 3.28 & 0.67 \\
\hline $\begin{array}{l}\text { Listening to instruction from foreign } \\
\text { manager }\end{array}$ & 13 & 29 & 2 & 2 & 3.19 & 0.70 \\
\hline $\begin{array}{l}\text { Listening to discussion in a } \\
\text { meeting/conference }\end{array}$ & 15 & 27 & 3 & 2 & 3.21 & 0.73 \\
\hline $\begin{array}{l}\text { Listening to British and American } \\
\text { accent }\end{array}$ & 21 & 19 & 8 & 0 & 3.27 & 0.74 \\
\hline Listening to job interview & 23 & 21 & 2 & 2 & 3.39 & 0.76 \\
\hline Listening to Engineering terminologies & 27 & 17 & 4 & 0 & 3.47 & 0.65 \\
\hline Listening to client's presentation & 17 & 28 & 2 & 2 & 3.26 & 0.71 \\
\hline $\begin{array}{l}\text { Listening to procedure or mechanical } \\
\text { engineering audio/video }\end{array}$ & 25 & 19 & 2 & 0 & 3.50 & 0.59 \\
\hline Listening to foreigner's conversation & 20 & 24 & 4 & 0 & 3.33 & 0.63 \\
\hline $\begin{array}{l}\text { Listening to foreign lecturer's } \\
\text { lecture }\end{array}$ & 20 & 20 & 3 & 0 & 3.39 & 0.62 \\
\hline
\end{tabular}

Table 3. The importance of each speaking sub-skill.

\begin{tabular}{lcccccc}
\hline Sub-skill Speaking & VI & I & U & VU & Mean & SD \\
\hline $\begin{array}{l}\text { Asking and answering materials } \\
\text { about geometrical shapes }\end{array}$ & 7 & 15 & 8 & 0 & 2,97 & 0.72 \\
\hline Promoting product & 12 & 18 & 8 & 0 & 3,11 & 0.72 \\
\hline $\begin{array}{l}\text { Explaining artificial and natural } \\
\text { process }\end{array}$ & 7 & 23 & 8 & 0 & 2,98 & 0.63 \\
\hline Communicating with foreigner & 16 & 19 & 7 & 0 & 3,22 & 0.71 \\
\hline Pronouncing vocabularies well & 21 & 22 & 1 & 1 & 3,4 & 0.65 \\
\hline Giving instruction to foreigners & 6 & 23 & 13 & 0 & 2,84 & 0.65 \\
\hline Having job interview & 18 & 24 & 1 & 1 & 3,35 & 0.64 \\
\hline Having conversation on phone & 7 & 27 & 11 & 0 & 2,92 & 0.63 \\
\hline $\begin{array}{l}\text { Speaking in British and American } \\
\text { accent }\end{array}$ & 9 & 19 & 8 & 0 & 3,10 & 0.69 \\
\hline Communicating with foreign client & 15 & 23 & 4 & 0 & 3,27 & 0.62 \\
\hline
\end{tabular}

Table 4. The importance of each reading sub-skill. 
Angga Nafis Akmal, Nur Hidayati, Rafika Rabba Farah
Exploring the English Needs of Mechanical Engineering Students in ESP Class: Indonesian University Context

\begin{tabular}{lcccccc}
\hline Subskill Reading & VI & I & U & VU & Mean & SD \\
\hline $\begin{array}{l}\text { Reading job-related text } \\
\text { (contract, rules, etc) }\end{array}$ & 23 & 17 & 3 & 1 & 3,41 & 0.72 \\
\hline Reading journal & 10 & 26 & 9 & 0 & 3,02 & 0.65 \\
\hline Reading product description & 13 & 25 & 7 & 0 & 3,13 & 0.66 \\
\hline Reading reference & 18 & 20 & 6 & 0 & 3,27 & 0.69 \\
\hline Understanding instruction of a text & 17 & 22 & 4 & 0 & 3,31 & 0.63 \\
\hline Understanding geometrical shapes text & 11 & 18 & 3 & 0 & 3,25 & 0.62 \\
\hline $\begin{array}{l}\text { Reading terminologies related to } \\
\text { mechanical engineering }\end{array}$ & 19 & 22 & 3 & 0 & 3,37 & 0.61 \\
\hline $\begin{array}{l}\text { Understanding a text about natural and } \\
\text { artificial process }\end{array}$ & 9 & 22 & 5 & 0 & 3,12 & 0.62 \\
\hline Reading mathematical formula & 17 & 24 & 1 & 0 & 3,38 & 0.53 \\
\hline Reading graphic and diagram & 12 & 24 & 4 & 0 & 3,20 & 0.61 \\
\hline
\end{tabular}

Table 5. The importance of each writing sub-skill

\begin{tabular}{lcccccc} 
Subskill Writing & VI & I & U & VU & Mean & SD \\
\hline Writing proposal & 19 & 19 & 0 & 0 & 3,5 & 0.50 \\
\hline Writing report & 18 & 15 & 9 & 2 & 3,12 & 0.85 \\
\hline Writing formal letter and memo & 8 & 23 & 8 & 0 & 3,00 & 0.65 \\
\hline $\begin{array}{l}\text { Writing position and location of } \\
\text { objects }\end{array}$ & 6 & 27 & 7 & 0 & 2,98 & 0.58 \\
\hline Writing essay & & & & & & \\
\hline Writing Mechanical procedure & 14 & 19 & 11 & 0 & 3,07 & 0.76 \\
\hline Writing Curriculum Vitae & 13 & 22 & 5 & 0 & 3,20 & 0.65 \\
\hline Writing Graphic Diagram & 4 & 24 & 9 & 0 & 2,87 & 0.58 \\
\hline Writing Mathematic Formula & 10 & 21 & 8 & 0 & 3,06 & 0.69 \\
\hline $\begin{array}{l}\text { Writing a paragraph about natural } \\
\text { and artificial process }\end{array}$ & 10 & 18 & 4 & 2 & 3,11 & 0.81 \\
\hline
\end{tabular}




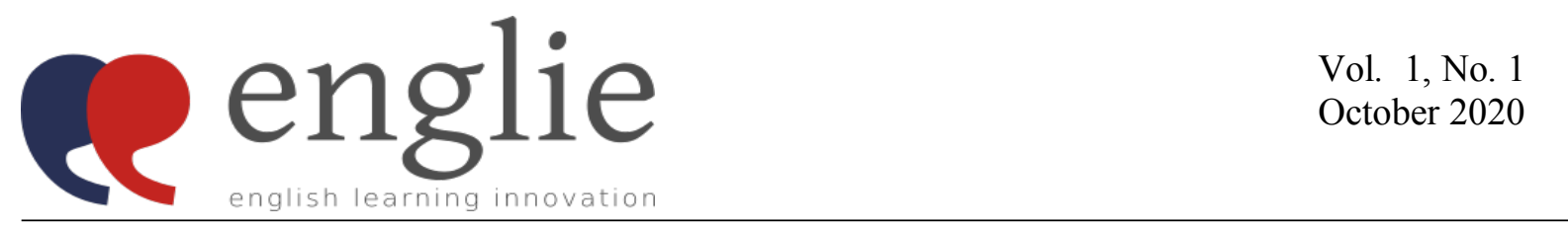

According to table 1, the most important skill chosen by participants is listening ( $M=3.58$; $\mathrm{SD}=0,53)$, followed by speaking $(\mathrm{M}=3.56 ; \mathrm{SD}=0.61)$, reading $(\mathrm{M}=3.36 ; \mathrm{SD}=0.63)$, and writing $(3.24 ; \mathrm{SD}=0.65)$. Listening skill has become the important skills considered by the Mechanical students.

Listening skill has been perceived as an important competence that they the respondents' need to master later in life. This perception brings the idea that listening material in Mechanical Engineering students is essential to be constructed in more occupational base. McDonough (2010) has identified 20 occupational areas that need effective communication, among others is engineering area. Thus, to communicate effectively in working area, listening skill become essential as it affects how one will produce spoken form. In constructing ESP listening material, ESP instructor can design listening syllabus with interactive listening - students will talk to another, and one-way listening such as listening to a talk or lecture (Goh, 2013). In a more comprehensive idea, ESP listening can give emphasize the competence on the core of listening comprehension skills, they are listening for details, listening for main ideas, listening for global understanding, listing and inference, listening and predicting, listening selectively (Vandergrift \& Goh, 2012). Those core skills can be adjusted to students' context and infused to their sub-skills. For example, engineering students needs to understand certain procedure on how to install equipment, thus, student will need the core skill of listening details.

\section{CONCLUSION}

The research reveals the needs of Mechanical Engineering students in terms of ESP. According to the findings of the research, the students perceive that listening is the most important skill for them followed by speaking, reading, and writing. Thus, for ESP lecturer, the finding of the research can be used as a reference to design ESP syllabus. For further researchers who intend to do the same research, the research syllabus here still needs to be re-evaluated and revised since the demand of global needs is always change. Hence, there will be appropriate syllabus for your era.

\section{REFERENCE}

Alsamadani, H. A. (2017). Needs Analysis in ESP Context: Saudi Engineering Students as a Case Study. Advances in Language and Literary Studies, 8(6), 58. https://doi.org/10.7575/aiac.alls.v.8n.6p.58

Ary, D., Jacobs, L. C., Sorensen, C., \& Razavieh, A. (2010). Introduction to Research in Education. United States: Wadsworth Cengage Learning.

Boroujeni, S. A., \& Fard, F. M. (2013). A Needs Analysis of English for Specific Purposes (ESP) Course For Adoption Of Communicative Language Teaching :( A Case of Iranian First-Year Students of Educational Administration). International Journal of Humanities and Social Science Invention ISSN, 2(6), 35-44. Retrieved from www.ijhssi.org

Goh, C. C. . (2013). ESP and Listening in Language Education and Assessment (D. Coniam, ed.). London: Springer. 
Hossain, J. (2013). ESP Needs Analysis for Engineering Students: A Learner Centered Approach. Journal of Presidency University, 2(2), 16-26.

Izidi, R., \& Zetouni, M. (2017). Esp Needs Analysis : The Case Of Mechanical Engineering Students At The University Of Sciences And Technology Oran U.S.T.O. Revue Des Études Humaines et Sociales, 16. https://doi.org/10.33858/0500-000-018054

Kaur, S., \& Khan, A. B. M. A. (2010). Language Needs Analysis of Art and Design Students: Considerations for ESP Course Design. ESP World, 9(2), 81-87. https://doi.org/10.1007/s13398-014-0173-7.2

Latief, M. A. (2017). Research Methods on Language Learning An Introduction, 6th $E d$. Malang: Universitas Negeri Malang.

Li, J. (2014). Needs Analysis: An Effective Way in Business English Curriculum Design. Theory and Practice in Language Studies, 4(9), 1869-1874. https://doi.org/10.4304/tpls.4.9.1869-1874

McDonough, J. (2010). English for specific purposes: A survey review of current materials. ELT Journal, 64(4), 462-477. https://doi.org/10.1093/elt/ccq060

Mihalache, R. (2015). Motivation VS Need of ESP of Engineering Students. The Journal of International Social Research, 8(36), 968-979.

Poedjiastutie, D. (2017). The Pedagogical Challenges of English for Specific Purposes (ESP) Teaching at the University of Muhammadiyah Malang, Indonesia. Educational Research and Reviews, 12(6), 338-349. https://doi.org/10.5897/ERR2016.3125

Saragih, E. (2014). Designing ESP Materials for Nursing Students Based On Needs Analysis. International Journal of Linguistics, 6(4), 59. https://doi.org/10.5296/ijl.v6i4.5983

Vandergrift, L., \& Goh, C. C. . (2012). Teaching and learning second language pragmatics. In Teaching and Learning Second Language Listening: Metacognition in Action. https://doi.org/10.4324/9781315716893

Williams, C. (2014). The future of ESP studies: building on success, exploring new paths, avoiding pitfalls. ASp, (66), 137-150. https://doi.org/10.4000/asp.4616 